\title{
The Relationship of CPTED and Fear of Crime in Gated and Non-Gated Residential
}

\author{
Siti Rasidah Md Sakip ${ }^{1}$, Noraini Johari ${ }^{1}$, Mohd Najib Mohd Salleh² \\ ${ }^{1}$ Faculty of Architecture, Planning \& Surveying, University Technology Mara Perak, 32610 \\ Bandar Seri Iskandar Perak, Malaysia \\ ${ }^{2}$ School of Housing Building and Planning, University Science of Malaysia, 11800 USM Penang, Malaysia \\ sitir704@perak.uitm.edu.my
}

\begin{abstract}
The built environment especially in terms of the residential design is believed to be one of the factors influencing crime and the level of fear of crime (FOC). People's perception of FOC varies considerably depending on their attitude and practices towards environmental conditions. CPTED is one of the most effective mechanisms to reduce FOC. Therefore, this paper investigates the relationship between practices and attitudes of CPTED and FOC in gated and non-gated residential areas. This study found that CPTED perception has a positive relationship with FOC $(r=0.36, p<0.01)$ while CPTED practices has a negative relationship with FOC $(r=-0.40, p<0.01)$.

Keywords: Crime; CPTED; fear of crime; built environment

eISSN 2398-4295 @ 2018. The Authors. Published for AMER ABRA cE-Bs by e-International Publishing House, Ltd., UK. This is an open-access article under the CC BY-NC-ND license (http://creativecommons.org/licenses/bync-nd/4.0/). Peer-review under responsibility of AMER (Association of Malaysian Environment-Behaviour Researchers), ABRA (Association of Behavioural Researchers on Asians) and cE-Bs (Centre for EnvironmentBehaviour Studies), Faculty of Architecture, Planning \& Surveying, Universiti Teknologi MARA, Malaysia.

DOI: http://dx.doi.org/10.21834/ajbes.v3i9.73
\end{abstract}




\subsection{Introduction}

The escalating rate of crime has become a serious concern in most countries. This is because it has led to rising fear of crime amongst residents who feel that they are constantly at risk (Nasar \& Jones, 1997). These acts of crime believed to be related to the physical environment (Cozens et al., 2005). Liebermann \& Kruger (2004) postulated that if an opportunity exists in a conducive environment, it will encourage a criminal to act on a targeted victim besides influenced by the criminal's willingness and ability to act as well as the targeted victim's vulnerability that attracted and induced the act of crime. Apparently, the environmental element is one of the factors considered by criminals in deciding whether or not to commit an act of crime (Anastasia \& John, 2007).

Various studies have found that the built environment do influence criminal behaviour (Cozens, David, \& Gwyn, 2001;Merry, 1981) where housing areas that not guarded or patrolled are more prone to become targets for acts of crime. In forming such control, interaction among factors including physical, social, environmental, individual, and community form the basis for environmental design and management as one of strategies to prevent crime. This may be related to the place-based method of crime prevention which refers to the steps taken to prevent or mitigate crime before it happens. This form of crime prevention focuses on all efforts aiming at reducing crime rates and fear of crime. Various crime prevention efforts such as Crime Prevention through Environmental Design (CPTED) focus on criminal spatial dimension and combine various strategies with the objective of changing criminal behavior. This study aims to investigate the relationship between CPTED's practices and attitudes of CPTED and fear of crime (FOC) in gated and non-gated residential area.

\subsection{Literature Review}

There are four approaches to crime prevention, namely: (a) the legal system or the enforcement of policed control systems (Dantzker \& Robinson, 2002); (b) social approaches (Bennet, Holloway, \& Farrington, 2006; Simons, 2002; Syarmila Hany, 2008; Welsh \& Hoshi, 2002); (c) approaches relating to the crime perpetrators (Paul Michael Cozens, Saville, \& Hillier, 2005); and, (d) approaches through environmental design (Brantingham \& Brantingham, 2005; Blakely \& Synder, 1997; Jacobs, 1961; Newman 1972). Each one of these approaches has their technique and different measurement methods in changing the behavioural patterns of an individual in committing crime.

Among the four methods of crime prevention as listed above, the Crime Prevention Through Environmental Design (CPTED) approach is perceived to have a stronger effect in influencing fear towards crime (Nasar \& Fisher, 1993). This is due to the fact that the CPTED approach involves constant elements that may be modified through planning and design. This has been proven through several research that discovered that the physical environment can open up opportunities for crimes to be committed (Anastasia \& John, 2007; Taylor \& Harrel, 1996). According to Lamya Rostami Tabrizi and Ali Madanipour (2006), physical layout, housing typologies as well as neighbourhood outlook and appearance are the main criteria that become the focus for the occurrence of crime. This aspect is believed to have a 
correlation with certain physical configurations which may generate more comfortable surroundings in which people can communicate and act in a better and easier way (Bynum \& Purri, 1984).

The concept of CPTED focuses on areas that often become the targets of acts of crime. It is emphasizing on techniques that can reduce acts of crime in the affected areas (Taylor \& Harrel, 1996). CPTED is a different approach in crime prevention. It may be expressed as physical environmental designs that may reduce the opportunity for criminal acts and thus reduce fear of crime through natural, mechanical and procedural means. This based on physical environmental characteristics that influence opportunities for crime to happen and affecting the criminal's perception on their targets for criminal acts (Taylor, 1996). Various studies have found that CPTED involves four main elements namely territoriality, surveillance, maintenance and access control.

Previous research demonstrates the relationships between elements of CPTED with fear of crime and crime itself such as Blobaum \& Hunecke (2005), and Schneider \& Kitchen (2007) on the relationships between surveillance and fear of crime, territoriality and fear of crime and crime itself (Aldrin, 1999; Newman, 1972) and maintenance with fear of crime (Cozens, Hillier, \& Prescott, 2001). However, research relating all the CPTED elements with fear of crime is limited. Recently, several studies have linked the relationship between CPTED elements with fear of crime (Clontz, 1995; Hedayati, 2009; Minnery \& Lim, 2005; Mohammad Abdul Mohit \& Elsawahli, 2010). Fear of crime defined as a perception that fear of crime related to emotional reactions, feeling of fear and distrust towards anything that may cause injury brought about by assault (Pain, 2000).

Studies relation on CPTED (Aldrin, 1999; Blobaum \& Hunecke, 2005; Chang, 2011; Cozens, Hillier et al., 2001; Hedayati, 2009; Minnery \& Lim, 2005; Newman, 1972; Perkins et al., 1992; Schneider \& Kitchen, 2007) focuses on CPTED practices rather than taking into consideration the respondents' perceptions on CPTED. Moreover, studies that examine the perception of CPTED and its relationship with CPTED practices and fear of crime are still rare. This assumption is in line with The Theory of Planned Behavior as proposed by Fishbein and Ajzen (1975). In the Theory of Planned Behavior proposed that a person's perception of a subject may motivate that person to act on the subject. For instance, a person who believes that the element of territoriality is able to reduce acts of crime will apply elements of territoriality at his residence to prevent acts of crime. Based on the theory behavior is an important to be considered in studying relationships between CPTED and fear of crime.

There is a large body of literature that supports the effectiveness of CPTED elements on fear of crime (Blobaum \& Hunecke, 2005; Pain, 2000; Schneider \& 
Kitchen, 2007) A study conducted by Schneider and Kitchen (2007). Most studies show the relationship between CPTED elements with fear of crime and indicated that some elements of CPTED can reduce fear of crime. More specifically, Schneider and Kitchen (2007) found that good surveillance using lighting at night is able to improve visibility of the surrounding area especially at the pedestrian área thus reducing fear of crime. Clear nocturnal visibility at a certain distance enables a person to act quickly against any action perceived to be a bodily threat to him (Blobaum \& Hunecke, 2005).

Elements of territoriality known as territorial functioning' are a social perspective which has significance in the advancement of the human lifestyle (Taylor, 1988). This related to the management of a space that requires the owner's actions and responsibility to ensure that space always cared for by displaying ownership characteristics; such as displaying signs of ownership, garden decorations, water features, landscaping and so on (Taylor, 1988). In addition, Brown and Altman (1981) found that a house that burglarised are most often houses that have weak territoriality space qualities such as signs of non-occupancy.

Natural surveillance believed to influence lack of criminal activities, which related with community relationship (Merry, 1981). Natural surveillance is a strategy that gives a perception to the potential criminal that there exists a risk that he will face in an area, making him feel that he watched; thus discouraging criminal intentions (Cozens et al., 2005). Surveillance can be achieved through natural and mechanical means. Natural surveillance involves the local community actions, the buildings' physical openings, and police patrol (Cozens et al., 2005). Mechanical surveillance, on the other hand, involves the use of surveillance tools such as CCTV (Jensen \& Anderson, 2004; Kajalo \& Lindblom, 2010).

Maintenance at the dwelling area helps the owner to give out a signal to outsiders that his dwelling always maintained and under watch (Cozens et al., 2005). Attention to the cleanliness of the dwelling and its surrounding areas expresses stronger place attachment, which related to crime and incivilities (Brown et al., 2004). A good image in terms of maintenance in the neighbourhood will create a perception that there are low social problems in the area (Crowe \& Zahm, 1994). Furthermore, poor maintenance believed to invite targeting of crime (Crowe \& Zahm, 1994; Wilson \& Kelling, 1982). Clontz (1995) found that a dwelling that poorly maintained has three times higher risk of being burglarised than a dwelling with a better image and which is better maintained.

Access control is a strategy aimed at reducing opportunities for commission of acts of crime by giving a perception to offenders of the risks they will face (Brantingham \& Brantingham, 1993; Cozens et al., 2005). These obstructions to target areas are in the form of fencing, solid walls, automatic locks, padlocks and alarm systems that obstruct and hinder burglary (Hirschfield, 2004). Various studies 
have proven that unsecured dwellings or properties have three times (Budd, 1999), and six times (Clontz, 1995) higher probabilities of burglarised than properties with basic security equipments.

Research has shown that some elements of CPTED were able to reduce or mitigate acts of crime (Brown et al., 2004; Crowe \& Zahm, 1994; Kajalo \& Lindblom, 2010; Perkins et al., 1993; Taylor, 1988; Wilson \& Kelling, 1982) which also perceived to reduce fear of crime (Newman, 1972). Recent research discussing the relationship between CPTED and fear of crime are by Hedayati (2009), as well as Minnery and Lim (2005) which found that fear of crime do not have a significant relationship with CPTED in dwelling areas. According to Hedayati (2009), this finding could be related to other factors such as speculations on crime, and social and psychological factors that have higher influences on fear of crime. In this context, it can be seen that elements of the physical environment have the ability to mitigate and prevent the commission of acts of crime.

\subsection{Methodology}

The study conducted in Putrajaya and Bandar Baru Bangi, which located in the central part of Malaysia. The study area in Putrajaya is Precint 9 Road B, which was the first neighbourhood to be built in Putrajaya (Roslan Talib, 2009) with 275 dwelling units. The area consisting of purely landed properties is a typical medium-high income housing area with two-storey terrace houses. The other study area was Bandar Baru Bangi which located near Putrajaya at a distance of approximately 15 kilometres (Putrajaya, 2009). The study area in Bandar Baru Bangi is Section 4 Road 4/7, which purely landed properties in a typical mediumhigh income housing area with two-storey terrace houses; which is similar with the study area in Putrajaya and consists of 201 dwelling units.

The two selected study areas consist of a population of 476 residents. Therefore, population survey taken as survey approach in this study. 20 households excluded from the study as these are unoccupied residences, such as vacant residences, nurseries and etc. This study included a structured questionnaire, which administered in the context of face-toface structured and formal interviews. The respondent in this study comprised of the main breadwinner in the household. Only 171 respondents participate in this study.

\subsection{Findings and Analysis}

The CPTED practices construct based on four dimensions, namely; (a) territoriality, (b) surveillance, (c) maintenance, and (d) access control. Meanwhile, CPTED perception construct based on three dimensions; (a) territoriality, (b) surveillance and, (c) maintenance. The perception of fear of crime (FOC) construct based on three dimensions; (a) physical environment, (b) social environment and, (c) indirect victimization. The validation and confirmation of all constructs done using Confirmatory Factor Analysis (CFA). CFA is a 
measurement model which developed by the correlation between latent variables and several indicators (items) or known as variable and error manifests. The CFA method is able to ensure and validate the items used in measuring latent variables by taking into account the value of the variances, as opposed to the factor analysis (FA) which only explores an item and suggests a factor for each of the items (Joreskog \& Sorbom, 1993). The result for the level of reliability found by calculating the Cronbach's Alpha. The dimensions of construct have a good reliability value as the Cronbach's Alpha value exceeds 0.60 (Nunnally \& Bernstein, 1994). The results indicated that the Alpha values for CPTED practices dimensions were territoriality (0.32), surveillance (0.65), and maintenance (0.62) and access control (-). The access control dimension involves only one item that do not require any reliability test and measurement model analysis to be done, hence the Alpha value could not be developed. The territoriality dimension, meanwhile, has an Alpha value of less than 0.60 $(a=0.32)$ which related to the total number of an item which was inadequate to measure the construct (Hair et al., 2006). This is because the Cronbach's Alpha value was sensitive towards the number of items used whereby if the number of items was small in the scale used, the Cronbach's Alpha value must therefore be small (Pallant, 2005). Based on this situation, the item to item correlation value from 0.2 to 0.4 are acceptable values to show the correlation between items (Pallant, 2005). The surveillance and maintenance dimensions meanwhile achieved good reliability levels (Nunnally \& Bernstein, 1994).

In terms of the CPTED perception construct, reliability results for every dimension indicated as follows: territoriality (0.75), surveillance $(0.74)$ and maintenance $(0.60)$. All these dimensions achieved good Alpha reliability levels (Nunnally \& Bernstein, 1994). The fear of crime (FOC) construct meanwhile shows Alpha reliability levels on three dimensions namely physical environment (0.93), social environment (0.93) and indirect victimisation (0.94). All FOC dimensions achieved good Alpha levels (Nunnally \& Bernstein, 1994).

Based on a population study, from the data of 171 respondents of this study, there was a significant difference between CPTED practices and type of residence $(t(169)=4.11 ; p=0.00)$ whereby respondents living in individual gated residential areas (IGR) $(M=7.76, S D=0.57)$ have higher CPTED practices as compared to respondents living in individual non-gated residential areas (INR) $(M=7.41, S D=0.52)$. Additionally, the CPTED practices dimension mean score of surveillance (INGR: $M=8.07$, IGR: $M=7.70$ ), access control (INGR: $M=3.79$, IGR: $M=3.16$ ), and maintenance (IGNR: $M=7.80$, IGR: $M=7.73$ ) were higher at individual non gated residential areas (INGR) compared to individual gated residential areas (INR). However, territoriality dimension's mean score found to be higher in individual gated residential areas (IGR:M=0.94, INGR: M=0.44). Figure 1show the result.

This study also found a significant difference between CPTED perception and type of residence $(t(169)=-3.80 ; p=0.00)$. This finding shows that respondents living in IGR $(M=6.44$,) type of residence have a higher CPTED perception compared to the respondents living in INGR (M=5.98) type of residence. Furthermore, the CPTED practices dimension mean score of territoriality (IGR: $M=6.68$, INGR: $M=6.16$ ), surveillance (IGR: $M=6.26$, INGR: $M=5.87$ ), and maintenance (IGR: $M=6.61$, INGR: $M=5.99$ ) were higher in IGR compare to INGR. Figure 2 show the result. 


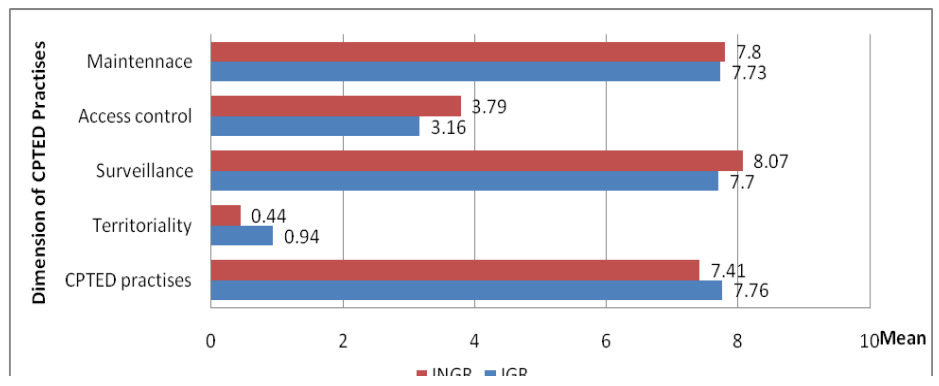

Fig. 1. Differences between CPTED practices at individual gated residential areas and non-gated residential areas with their dimensions

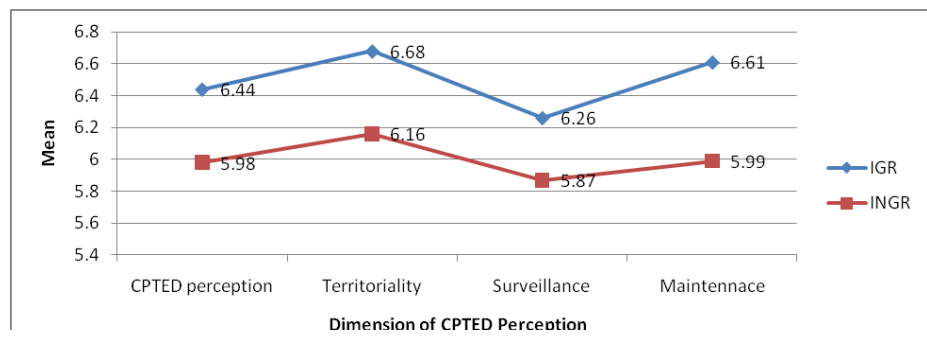

Fig. 2. Differences between CPTED practices at individual gated residential areas and non-gated residential areas with their dimensions

The study found a significant difference between fear of crime (FOC) and the type of residence $(t(146.17)=-8.59 ; p=0.00)$. Respondents living in IGR type of residence have higher FOC as compared to respondents living in INGR type of residence. This based on a FOC mean score of (M=5.92) on IGR type of residence which is higher than a FOC mean score of $(M=3.92)$ on INGR type of residence. Besides that, the FOC dimensions of the physical environment (IGR: $M=5.80$, INGR: $M=3.85$ ), social environment (IGR: $M=6.01$, INGR: $M=3.99$ ), and indirect victimisation (IGR: $M=5.74$, INGR: $M=3.73$ ) were also higher for respondents living in IGR compare to INGR. Figure 3 show the result.

Pearson's correlation results on the correlation between the three constructs of CTED practices, CPTED perception and fear of crime (FOC), indicated that CPTED perception has a medium strong, significant and positive relationship with fear of crime (FOC) ( $r=0.36$, $p<0.01$ ). These findings show that if a respondent has a high perception that CPTED is able to prevent crime in neighbourhood areas, fear of crime will be an increase. Meanwhile, CPTED practices found to have a significant, but negative relationship $(r=-0.40, p<0.01)$ with 
fear of crime. This finding states that as CPTED practices increases, fear of crime will be reduced.

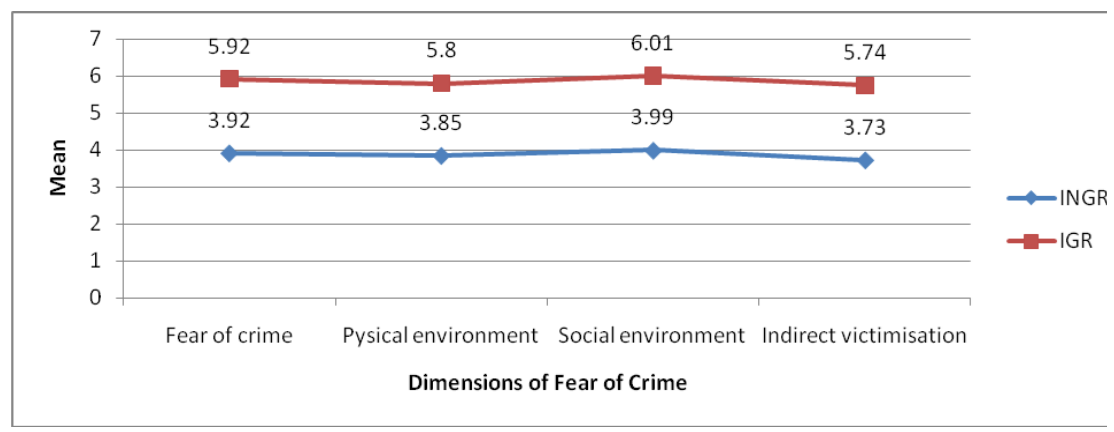

Fig. 3. Differences between Fear of Crime at individual gated residential areas and non-gated residential areas with their dimensions

\subsection{Conclusion}

The objective of this paper is to investigate the relationship between CPTED practices with CPTED perception and fear of crime at two types of residences namely individual gated residential areas (IGR) and individual non-gated residential areas (INGR). The findings of this study proved that there is a relationship between CPTED practices with CPTED perception and fear of crime. Simultaneously, this study also proved that high CPTED practices are able to reduce fear of crime. These findings support various previous studies that elements of CPTED are able to reduce fear of crime. In addition, this finding could also have implications for the parties that involved in the development as an architect, landscape architect, planner and developer to ensure the application of CPTED elements in residential areas to eliminate of crime. This paper also contributes to the body of knowledge which states that perceptions towards CPTED also have relationships with CPTED practices and fear of crime. It is recommended that in future studies, a detailed study on all three variables at different residential areas such as flats, semi-detached houses and terrace houses must be conducted to investigate the relationships between these variables.

\section{References}

Aldrin, A. (1999). Crime Landscape: The Relationship of Victimisation and Fear of Crime With Residents' Territorial Functioning in High and Low Crime Rate Estate in Sheffield University of Sheffield, U.K.

Anastasia, L.-S., \& John, E. E. (2007). Crime Prevention and Active Living American Journal of Health Promotion, 21(4), 380-389. 
Bennet, T., Holloway, K., \& Farrington, D. P. (2006). Does Neighborhood Watch Reduce Crime? A Systematic Review and Meta-Analysis. Journal of Experimental Criminology, 2, 437-458.

Blobaum, A., \& Hunecke, M. (2005). Perceived Danger in Urban Public Space; The Impacts of Physical Features and Personal Factors. Environment and Behavior, 37(4), 465-486.

Boeting, B. P. (2006). The Routine Activity Theory: A Model for Addressing Specific Crime Issues. ProQuest Social Science Journals, 75(6), 12-19.

Brantingham, \& Brantingham. (1993). Nodes, Paths and Edges: Considerations on The Complexity of Crime and The Physical Environment. Journal of Environmental Psychology, 13(1), 3-28.

Brantingham, P. L., \& Brantingham, P. J. (2005). Situational Crime Prevention as a Key Component in Embedded Crime Prevention. Canadian Journal of Criminology and Criminal Justice, 271-288.

Blakely, E. J., \& Synder, M. G. (1997). Fortress America Gated Communities in The United States. Washington D. C: Brookings Institution Press.

Brown, B. B., \& Altman, I. (1981). Territoriality and residential crime: A conceptual framework. Environmental criminology, 55-76.

Brown, B. B., \& Bentley, D. L. (1993). Residential burglars judge risk: the role of territoriality. Journal of Environmental Psychology, 13(1), 51-61.

Budd, T. (1999). Burglary of domestic dwellings: Findings from the British Crime Survey. Statististical Bulletin-Home Office Research Development and Statistics Directorate 4/99.

Bynum, T. S., \& Purri, D. M. (1984). Crime and Architectural Style: An Examination of the Environmental Design Hypothesis. Criminal Justice and Behavior, 11(2), 179-196.

Chang, D. (2011). Social crime or spatial crime? Exploring the effects of social, economical, and spatial factors on burglary rates. Environment and Behavior, 43(1), 26-52.

Clontz, K. A. (1995). Residential and Commercial Burglaries: An Empirical Test of Crime Prevention Through Environmental Design. Florida State University.

Cozens, David, H., \& Gwyn, P. (2001). Crime and The Design of Residential Property Exploring The Theoretical Background Part 1. Property Management, 19(2), p136-164.

Cozens, Hillier, D., \& Prescott, G. (2001). Crime and The Design of Residential Property - Exploring the Perceptions of Planning, Professionals, Burglars and Other Users Part 2. Property Management, 19(4), 222-248.

Cozens, P. M., Saville, G., \& Hillier, D. (2005). Crime Prevention Through Environmental Design (CPTED): A Review and Modern Bibliography. Property Management, 23(5), 328-356.

Craik, K. H., \& Appleyard, D. (1980). Streets of San Francisco: Brunswik's Lens Model Applied to Urban Inference and Assessment Journal of Social Issues, 36(3), 72-85.

Crowe, T., \& Zahm, D. (1994). Crime Prevention Through Environmental Design. NAHB Land Development Magazine, 22.

Dantzker, M. L., \& Robinson, D. M. (2002). Perspectives on Crime Prevention A Capstone View. In D. M. Robinson (Ed.), Policing and Crime Prevention United States: Pearson Education, Inc. 
Fishbein, M., \& Ajzen, I. (1975). Belief, Attitude, Intention and Behavior: An Introduction to Theory and Research. United States, America: Addison-Wesley Publishing Company.

Hedayati, M. M. (2009). Perception of Crime and An Assessment of Crime Prevention Through Environmental Design (CPTED) Elements in A Housing Area: A Case Study of Minden Heights in Penang. University Science Malaysia, Pulau Pinang.

Hirschfield, A. (2004). The impact of the reducing burglary initiative in the north of England. Home Office Online Report, 40(04).

Jacobs, J. (1961). The Death and Life of Great American Cities. New York: : Random House.

Jeffery, C. R. (1971). Crime Prevention through Environmental Design: Sage, Beverrly Hills, CA.

Jensen, J., \& Anderson, J. (2004). Crime Prevention Through Environmental Design Criminology 420- Term Paper.

Joreskog, K., \& Sorbom, D. (1993). Lisrel 8: Structural Equation Modeling With The SIMPLIS Command Language. Chicago: Scientific Software International, Inc.

Kajalo, S., \& Lindblom, A. (2010). How Retail Entrepreneurs Perceive the Link Between Surveillance, Feeling of Security, and Competitiveness of the Retail Store? A Structural Model Approach. Journal of Retailing and Consumer Services, 17, 300-305.

Lamya Rostami Tabrizi \& Ali Madanipour (2006) Crime and The City: Domestic Burglary and The Built Environment in Tehran. Habitat International, 10, 932-944.

Liebermann, S., \& Kruger, T. (2004). Crime Prevention Through Environmental Design (CPTED). Paper presented at the 9th International Conference on Crime Prevention Environmental Design

Merry, S. E. (1981). Defensible Space Undefended: Social Factors in Crime Control Through Environmental Design. Urban Affairs Review, 16(4), 397-422.

Minnery, J. R., \& Lim, B. (2005). Measuring Crime Prevention Through Environmental Design. Journal of Architectural and Planinng Research, 22(4), 330-341.

Mohammad Abdul Mohit, \& Elsawahli, H. M. H. (2010). Crime and Housing in Malaysia: Case Study of Taman Melati Terrace Housing in Kuala Lumpur. Asian Journal of Environment-Behaviour Studies, 1(3), 26-36.

Nasar, \& Jones. (1997). Landscapes of Fear and Stress. Environment and Behavior, 29(3), 291-323.

Newman, O. (1972). Crime Prevention Through Urban Design Defensible Space. New York: The Macmillan Company.

Nunnally, J. C., \& Bernstein, I. H. (1994). Psychometric Theory. New York: McGraw-Hill.

Pain, R. (2000). Place, Social Relations and The Fear of Crime: A Review. Progress in Human Geography, 24(3), 365-387.

Pallant, J. (2005). SPSS Survival Manual; A Step by Step Guide to Data Analysis Using SPSS for Windows. Sydney, Australia: Allen \& Unwin.

Perkins, Weeks, J. W., \& Taylor, R. B. (1992). The Physical Environment of Street Blocks and Resident Perceptions of Crime and Disorder: Implicatons for Theory and Measurement. Journal of Environmental Psychology, 12(1), 21 . 34. 
Putrajaya, P. (2009). Laporan Pemeriksaan; Draf Rancangan Struktur Putrajaya. Putrajaya: Perbadanan Putrajayao. Document Number)

Schneider, R. H., \& Kitchen, T. (2007). Crime Prevention and The Built Environment. New York: Routledge, New York.

Syarmila Hany, H. (2008). The Relationship Between Territorial Functioning and Victimisation, Fear of Crime, Neighbourhood Watch and Ethnic Relations: A Case Study of Subang Jaya Housing Scheme. Universiti Sains Malaysia, Penang.

Taylor, R. B., \& Harrel, A. V. (1996). Physical Environment and Crime. United State: U.S Department of Justiceo. Document Number)

Simons, C. F. (2002). The Evolution of Crime Prevention. In D. M. Robinson (Ed.), Policing and Crime Prevention. United States: Pearson Education, Inc.

Shaw, K. T., \& Gifford, R. (1994). Resident's and burglars' assessment of burglary risk from defensible space cues. Journal of Environmental Psychology, 14(3), 177-194.

Taylor, R. (1996). Neighborhood Responses to Disorder and Local Attachments: The Systemic Model of Attachment, Social Disorganization, and Neighborhood Use Value. Sociological Forum, 11(1).

Taylor, R. B. (1988). Human Territorial Functioning: An Empirical, Evolutionary Perspective on Individual and Small Group Territorial Cognitions, Behaviours and Consequences. Cambridge: Cambridge University Press.

Taylor, R. B., \& Hale, M. (1986). testing Alternative Models of Fear of Crime. Journal of Criminal Law and Criminology, 77(1), 151-189.

Welsh, B. C., \& Hoshi, A. (2002). Communities and Crime Prevention. In Evidence-Based Crime Prevention. New York: Routledge.

Wilson, J. G., \& Kelling, G. L. (1982). Broken Windows: The Police and Neighbourhood Safety. Atlantic Monthly, March, 29-38. 